\title{
The effect of heat treatment on mechanical properties and microstructure of the AISI 422 martensitic stainless steel
}

\author{
H. Babaei*, K. Amini**, A. Shafyei*** \\ *Department of Materials Engineering, Najafabad Branch, Islamic Azad University, Najafabad, Iran \\ **Department of Mechanical Engineering, Tiran branch, Islamic Azad University, Tiran, Iran \\ ***Department of Materials Engineering, Isfahan University of Technology, Isfahan, Iran
}

cross $^{\text {ref }}$ http://dx.doi.org/10.5755/j01.mech.22.6.13599

\section{Introduction}

Martensitic stainless steels have good mechanical properties and good corrosion resistance. For these reasons, they have a wide application in petrochemical, marine, aerospace, and food industries [1-5]. AISI 422 is used in nuclear power plants, dental tools, and surgical knives. Heat treatment plays an important role in this grade. Hence precise control of the heat treatment process to obtain martensite layers, least delta ferrite, and retained austenite is very important [6]. Moreover, carbon and alloy content in austenite have a substantial effect on strength and impact energy. The proposed heat treatment for grade AISI 422 is: a) austenitizing to temperature $1000-1050^{\circ} \mathrm{C}$ for $60 \mathrm{~min}$ and quenching in oil; b) tempering in the temperature range of $200-300^{\circ} \mathrm{C}$ for $60 \mathrm{~min}$ for achieving high tensile strength and fair toughness and second tempering in the range of $600-700^{\circ} \mathrm{C}$ for $60 \mathrm{~min}$ is preferred for getting fair strength with high toughness which should be carried out carefully [7].

Studies by Shafer et al. [8] on Cr-martensitic steels were carried out to find the effect of delta ferrite and dendritic carbides precipitated on the delta ferrite boundaries which caused the drop in impact energy. Wang et al. [9] believed that the presence of delta ferrite in microstructure reduced the impact energy in martensitic steel $13 \mathrm{Cr}-4 \mathrm{Ni}$. In studies by calliari et al. [10] on martensitic steel Ni-Mo to find out effect of tempering temperature on hardness, revealed the effect of secondary hardening in temperatures $500-560^{\circ} \mathrm{C}$. Type AISI 422 is a hardenable (martensitic) $13 \%$ chromium stainless steel that is a modification of type AISI 420. The modification consists of additions of nickel, molybdenum, tungestan and vanadium that improve the elevated temperature strength and resistance to stress corrosion and minimize anisotropic behavior. Good creep-rupture properties of about $480^{\circ} \mathrm{C}$ and resistance to stress-corrosion cracking in the heat treated condition make this grade suitable for applications in jet engines. Other uses include buckets for steam and gas turbines, discs, bolts, wheel and blades, as well as structural components of aircraft and missiles. This alloy is also used for a number of valve applications. Given the need to obtain high strength and impact energy in grade AISI 422, in present research, the effect of austenitizing temperature and tempering time on strength and impact as well as microstructure has been evaluated.

\section{Testing procedures}

The composition of studied martensitic stainless steel AISI422 was as follows (in wt \%): $0.21 \mathrm{C}, 0.29 \mathrm{Si}, 0.62$
Mn, 0.022 P, 0.006 S, 12 Cr, 0.96 Mo, 0.9 Ni, 0.11 Cu, 0.014 $\mathrm{Al}, 0.26 \mathrm{~V}, 1 \mathrm{w}$. A billet with final diameter $397 \mathrm{~mm}$ and length $2000 \mathrm{~mm}$ obtained in an electric furnace was forged at $1150-1180^{\circ} \mathrm{C}$ and annealed at $780^{\circ} \mathrm{C}$. The specimens were heat treated at a rate of $8 \mathrm{~K} / \mathrm{min}$ to $620^{\circ} \mathrm{C}$, held for $30 \mathrm{~min}$, continued heating with the same rate to the austenitizing temperature of $1040^{\circ} \mathrm{C}(\mathrm{SA} 1)$ and $1070^{\circ} \mathrm{C}(\mathrm{SA} 2)$, holding time of $60 \mathrm{~min}$ and then quenched in oil at $30^{\circ} \mathrm{C}$, and finally tempered at $700^{\circ} \mathrm{C}$ for $120 \mathrm{~min}$. To study the effect of the tempering temperature on mechanical properties, the specimens were subjected to austenitization at $1040^{\circ} \mathrm{C}$ for $60 \mathrm{~min}$, quenched in oil and tempered for $2 \mathrm{~h}$ at various temperatures, i.e., 300, 400, 500, 600, 700. To study the effect of the duration of the tempering the specimens of the $\mathrm{SA} 1$ series were tempered at $700^{\circ} \mathrm{C}$ for 2 and $5 \mathrm{~h}$. Then they were polished against a No. 1000 (the number of grain per square inch) emery paper to provide a uniform surface roughness.

The tensile test was performed using a ZWICK Z 250 tensile testing machine in accordance with the DIN 250120 standard at room temperature $\left(30 \pm 5^{\circ} \mathrm{C}\right.$, moisture content $50 \pm 10 \%$ ) at a deformation rate of $4 \mathrm{~mm} / \mathrm{min}$. The impact test was performed by the Charpy method in accordance with EN 100-45 standard. The Rockwell hardness was measured using an EMCO M4U 750 hardness tester in accordance with DIN-EN 6508. The x-ray diffraction studies were performed using a Philips PW37 diffractometer in $\mathrm{Cuk}_{\alpha}$ radiation. The grain size was determined according to the ASTM E112 standard. The structure was studied by using an Olympus PMG3 microscope. The structure was etched with a Villela etchant $(1 \mathrm{~g}$ picric acid, $10 \mathrm{ml}$ hydrochloric acid, $100 \mathrm{ml}$ ethanol). The EDS analysis was utilized to identify the carbides decomposed at different tempering temperature

\section{Results and discussion}

\subsection{The effect of austenitizing temperature}

Microstructure of the specimens after treatments SA1 and SA2 is presented in Fig. 1, a, b. When the austenitizing temperature is increased from 1040 to $1070^{\circ} \mathrm{C}$, the grain size increases from the initial No. 8 to No. 7 (ASTM), due to the dissolution of the carbides. Fig. 1, c, d shows the tempered martensite layers. Table 1 presents the values of the hardness of the ultimate rupture strength and the impact energy. When the asutenization temperature is increased from 1040 to $1070^{\circ} \mathrm{C}$, the hardness and ultimate rupture is increased. Variation of hardness and ultimate rupture 
strength can be attributed to the increase of alloying elements such as chromium and carbon in the austenite with the increase of temperature.

The increase of the temperature increases the carbide dissolution in the matrix. Garcia et al. [1] showed that in the AISI 420 stainless steel, the increase of austenitizing temperature decreased carbides from $9.9 \%$ to $6.6 \%$. The strength increase is resulted from the dissolution of the $\mathrm{M}_{23} \mathrm{C}_{6}$ carbide in the matrix which increases the carbon super-saturation and lattice distortion of the martensite [11] together with the amount of twin boundaries and dislocations in the microstructure [12].

Refinement of the austenite grains causes an increase in the impact energy of specimen SA1 as compared to specimen SA2. In studies by Choi et al. [13] on alloy 03C14Cr-3Mo about effect of austenitizing temperature and primary austenite grain size has been investigated. In this study it is believed that more dissolution of carbides by increasing the austenitizing temperature from 1000 to $1030^{\circ} \mathrm{C}$ was the main cause of grain growth.

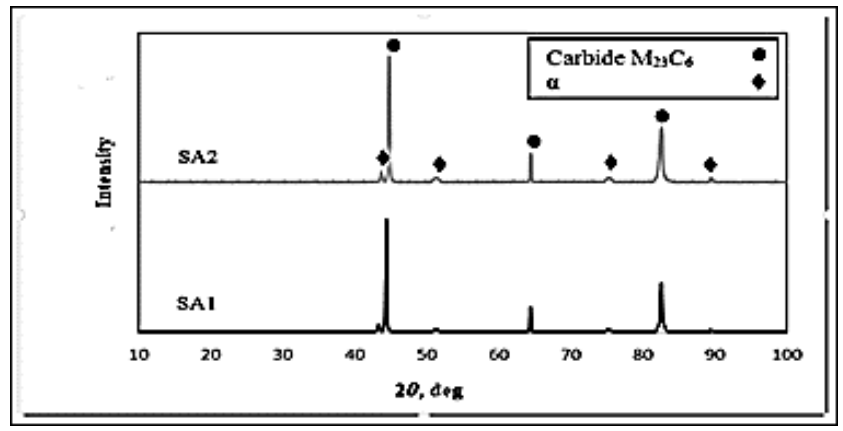

Fig. 2 X-ray diffractogram of specimens SA1 and SA2

The diffractogram of specimens SA1 and SA2 show the presence of an $\mathrm{M}_{23} \mathrm{C}_{6}$ carbide in the final structure (Fig. 2).

Hardness (HRC), Ultimate rupture strength $\left(\sigma_{r}\right)$, and Impact energy $\left(U_{i m}\right)$ of stainless Steel AISI 422

\begin{tabular}{|c|c|c|c|}
\hline Specimen & HRC & $\sigma_{r}, \mathrm{MPa}$ & $U_{\text {im }}, \mathbf{J}$ \\
\hline SA1 & 30 & 1041 & 27.7 \\
\hline SA2 & 36 & 1059 & 20 \\
\hline
\end{tabular}

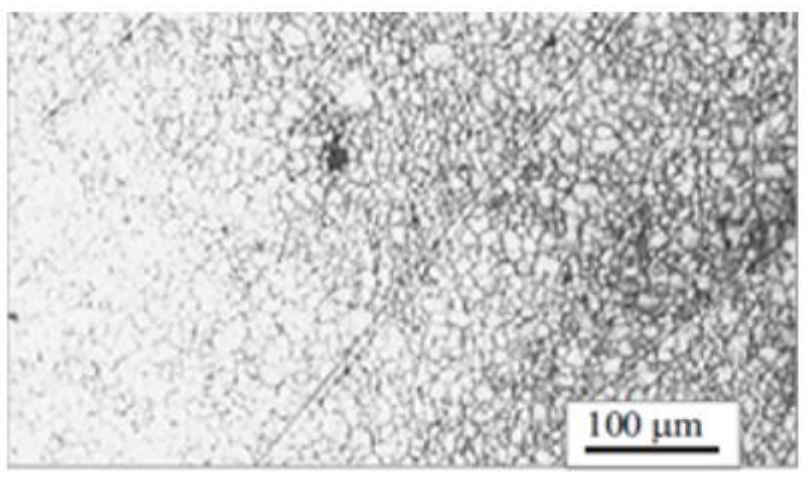

a

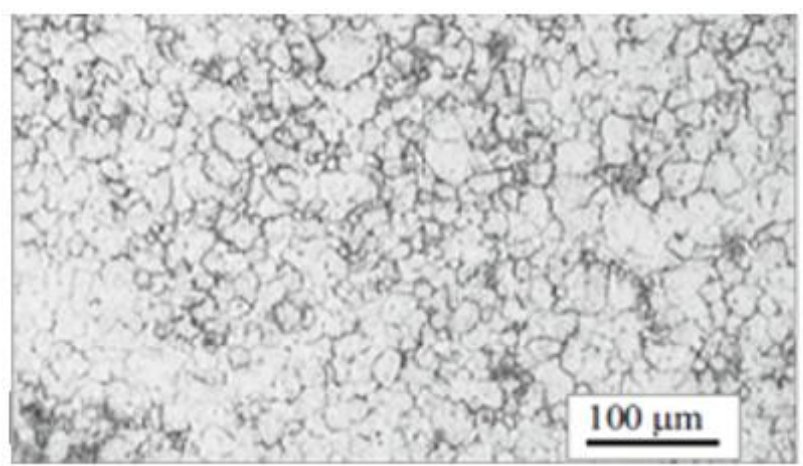

b

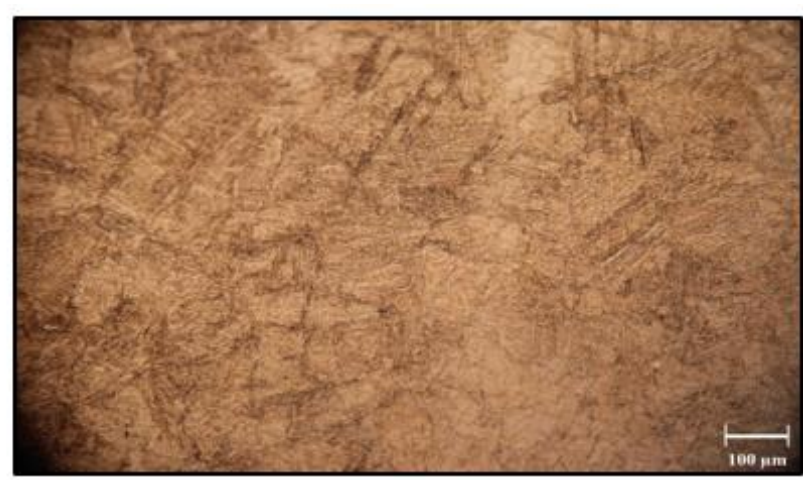

$\mathrm{c}$

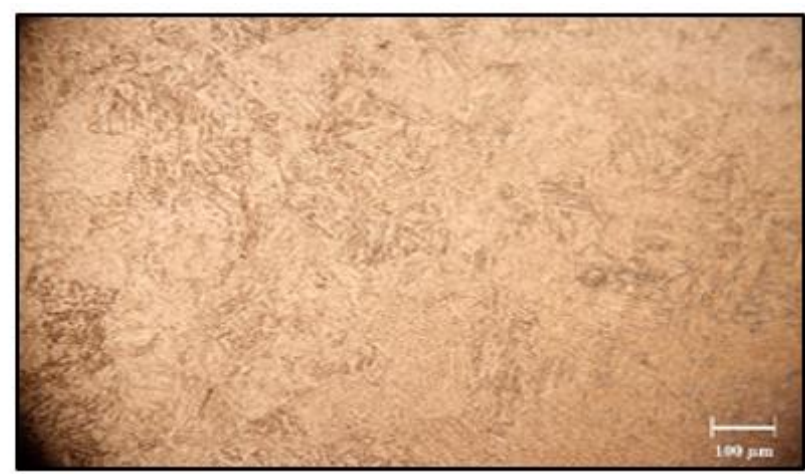

d

Fig. 1 Microstructure of steel AISI 422 specimens after different treatments: a - initial austenite grain of SA1; b - initial austenite grain of SA2; c - tempered martensite layer of SA1; - tempered martensite layer of SA2

\subsection{The effect of tempering temperature}

The optimum impact energy was observed when austenitizing occurred at $1040^{\circ} \mathrm{C}$ for $60 \mathrm{~min}$. This cycle was selected for the next tests. To evaluate the effect of temper- ing temperature on mechanical properties and microstructure, tempering treatments were conducted in the range of $300-700^{\circ} \mathrm{C}$ for $2 \mathrm{~h}$. In Fig. 3 the hardness value of the specimens quenched and tempered at various temperatures are shown.

As can be seen, hardness remains almost constant 
for tempering temperatures ranging from $300^{\circ} \mathrm{C}$ to $400^{\circ} \mathrm{C}$. Increasing hardness during tempering in the range of 400 $500^{\circ} \mathrm{C}$ can be attributed to the secondary hardening phenomenon. This is generally associated with the formation of the $\mathrm{M}_{7} \mathrm{C}_{3}$ carbides within the martensite lath. It can also be observed in Fig. 3 that hardness decreases when tempering in the range of $500-700^{\circ} \mathrm{C}$. This softening occurred when the $\mathrm{M}_{7} \mathrm{C}_{3}$ carbides started to coarsen and partially transform to the $\mathrm{M}_{23} \mathrm{C}_{6}$ carbides. Fig. 5 shows the result of EDS analysis for the specimens that were tempered at $500^{\circ} \mathrm{C}$ and $700^{\circ} \mathrm{C}$ respectively. EDS results together with the results reported by Calliari et al. [10] in similar stainless steel showed that the identified carbides at $500^{\circ} \mathrm{C}$ and $700^{\circ} \mathrm{C}$ could be $\mathrm{M}_{7} \mathrm{C}_{3}$ and $\mathrm{M}_{23} \mathrm{C}_{6}$ respectively.

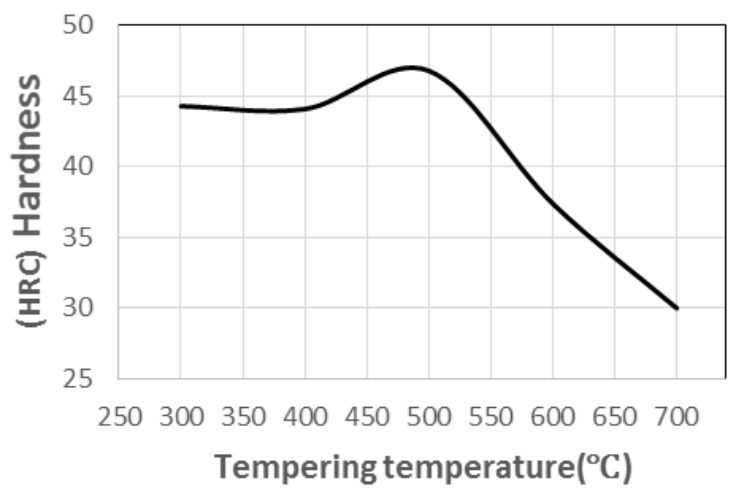

Fig. 3 hardness versus tempering temperatures

Studies by Balan et al. [3] on martensitic stainless steel $16 \mathrm{Cr}-2 \mathrm{Ni}$ shows the secondary hardening in the temperature range of $300-450^{\circ} \mathrm{C}$. They believed that the precipitation of the $\mathrm{M}_{7} \mathrm{C}_{3}$ carbides for secondary hardening and the tempering temperature of $450-650^{\circ} \mathrm{C}$ the transformation of the $\mathrm{M}_{7} \mathrm{C}_{3}$ carbides to $\mathrm{M}_{23} \mathrm{C}_{6}$ as well as grain growth. Amini et al. [14] reported that secondary hardening occurred in martensitic stainless steel DIN 1.4057 in the range of 350$420^{\circ} \mathrm{C}$ due to precipitation of the $\mathrm{M}_{7} \mathrm{C}_{3}$ carbides and resulted decreasing hardness in the range of $450-650^{\circ} \mathrm{C}$ is due to $\mathrm{M}_{7} \mathrm{C}_{3}$ to $\mathrm{M}_{23} \mathrm{C}_{3}$ transformation. These studies are similar to the result of studies by Naseri et al. [7] on martensitic stainless steel AISI 420 in which the secondary hardening effect was seen at $400-500^{\circ} \mathrm{C}$.

The impact strength (Fig. 4) decreased when tempering temperature increased from $300-500^{\circ} \mathrm{C}$ so that the least impact strength was observed at $500^{\circ} \mathrm{C}$. Reduction of impact energy with increasing the tempering temperature to $500^{\circ} \mathrm{C}$ could have been resulted from reducing the retained austenite volume fraction, increasing carbide particle and also re-precipitation of phosphorous at grain boundaries [2]. Impact strength increased again at $700^{\circ} \mathrm{C}$, because martensite tempered and a recovery took place at this temperature.

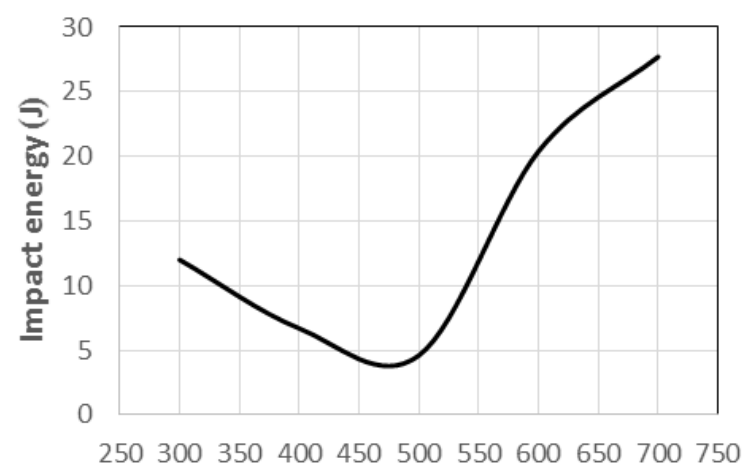

Tempering temperature $\left({ }^{\circ} \mathrm{C}\right)$

Fig. 4 Impact energy versus tempering temperatures

In Table 2 the behavior of yield strength and tensile strength by tempering temperature is shown. As can be seen, with increasing the tempering temperature, in the beginning the yield and tensile strength change inconsiderably but in the range $400-500^{\circ} \mathrm{C}$, both properties increase and again in the range $500-700^{\circ} \mathrm{C}$ the yield and tensile strength decrease.

Ultimate rupture strength and yield strength of steel ASI 422 as a function of the tempering temperature

Table 2

\begin{tabular}{|c|c|c|}
\hline Tempering temperature, ${ }^{\circ} \mathrm{C}$ & Yield strength, $\mathrm{MPa}$ & Ultimate rupture strength, MPa \\
\hline 300 & 1359 & 1579 \\
\hline 400 & 1366 & 1598 \\
\hline 500 & 1394 & 1620 \\
\hline 600 & 1130 & 1270 \\
\hline 700 & 883 & 1041 \\
\hline
\end{tabular}

\subsection{The effect of the tempering time}

To evaluate the effect of the tempering time on specimen (austenitized at $1040^{\circ} \mathrm{C}$ ), it was tempered at $700^{\circ} \mathrm{C}$ for 2 and 5 hours. Then the impact test was carried out on the specimens. The result is shown in Table 3.

Table 3

Impact energy of the AISI 422 steel as a function of the duration of tempering

\begin{tabular}{|c|c|c|}
\hline Specimen & Tempering time, $\mathrm{h}$ & Impact energy, $\mathrm{J}$ \\
\hline SA1-2h & 2 & 27.7 \\
\hline SA1-5h & 5 & 35.1 \\
\hline
\end{tabular}

Also, the microstructure of these specimens (SA12h\&SA1-5h) was studied by SEM (Fig. 6). By increasing the tempering time from 2 to 5 hours, the size of the precipitated carbides increased from $0.59 \mu \mathrm{m}$ to $0.74 \mu \mathrm{m}$. According to Table 3, the impact energy increases from 27.7 to 35.1 Joules. The studies by Ning et al. [15] on hyper martensitic stainless steel at the tempering temperature of $600^{\circ} \mathrm{C}$ for 6 and 12 hours showed that with increasing the tempering time, the retained austenite grains are elongated and the percentage of retained austenite increases and they inferred that the percentage of retained austenite is the cause of increase in the impact energy. 

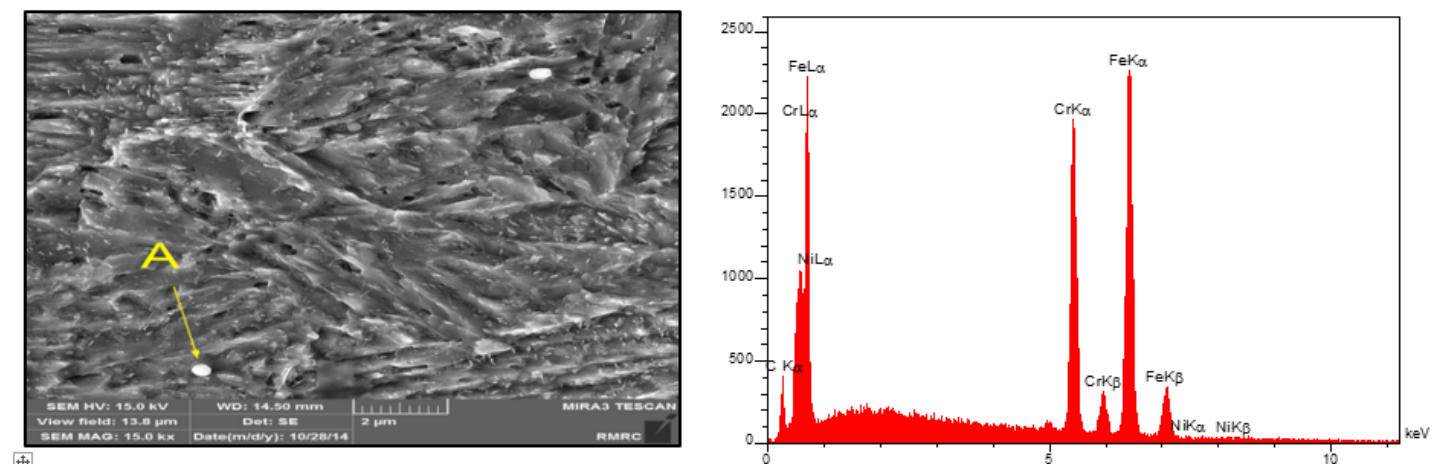

\begin{tabular}{|c|c|c|c|c|c|c|c|c|c|}
\hline Elt & Line & Int & Error & $\mathrm{K}$ & $\mathrm{Kr}$ & $\mathrm{W} \%$ & $\mathrm{~A} \%$ & $\mathrm{ZAF}$ & Ox\% \\
\hline $\mathrm{C}$ & $\mathrm{Ka}$ & 121.1 & 126.9669 & 0.1073 & 0.0851 & 24.35 & 58.99 & 0.3495 & 0.00 \\
\hline $\mathrm{Cr}$ & $\mathrm{Ka}$ & 959.5 & 2.2450 & 0.5112 & 0.4053 & 41.47 & 23.21 & 0.9772 & 0.00 \\
\hline $\mathrm{Fe}$ & $\mathrm{Ka}$ & 495.1 & 2.2450 & 0.3801 & 0.3013 & 34.06 & 17.74 & 0.8847 & 0.00 \\
\hline $\mathrm{Ni}$ & $\mathrm{Ka}$ & 1.1 & 2.2450 & 0.0014 & 0.0011 & 0.12 & 0.06 & 0.8837 & 0.00 \\
\hline & & & & 1.0000 & 0.7927 & 100.00 & 100.00 & & 0.00 \\
\hline
\end{tabular}

a
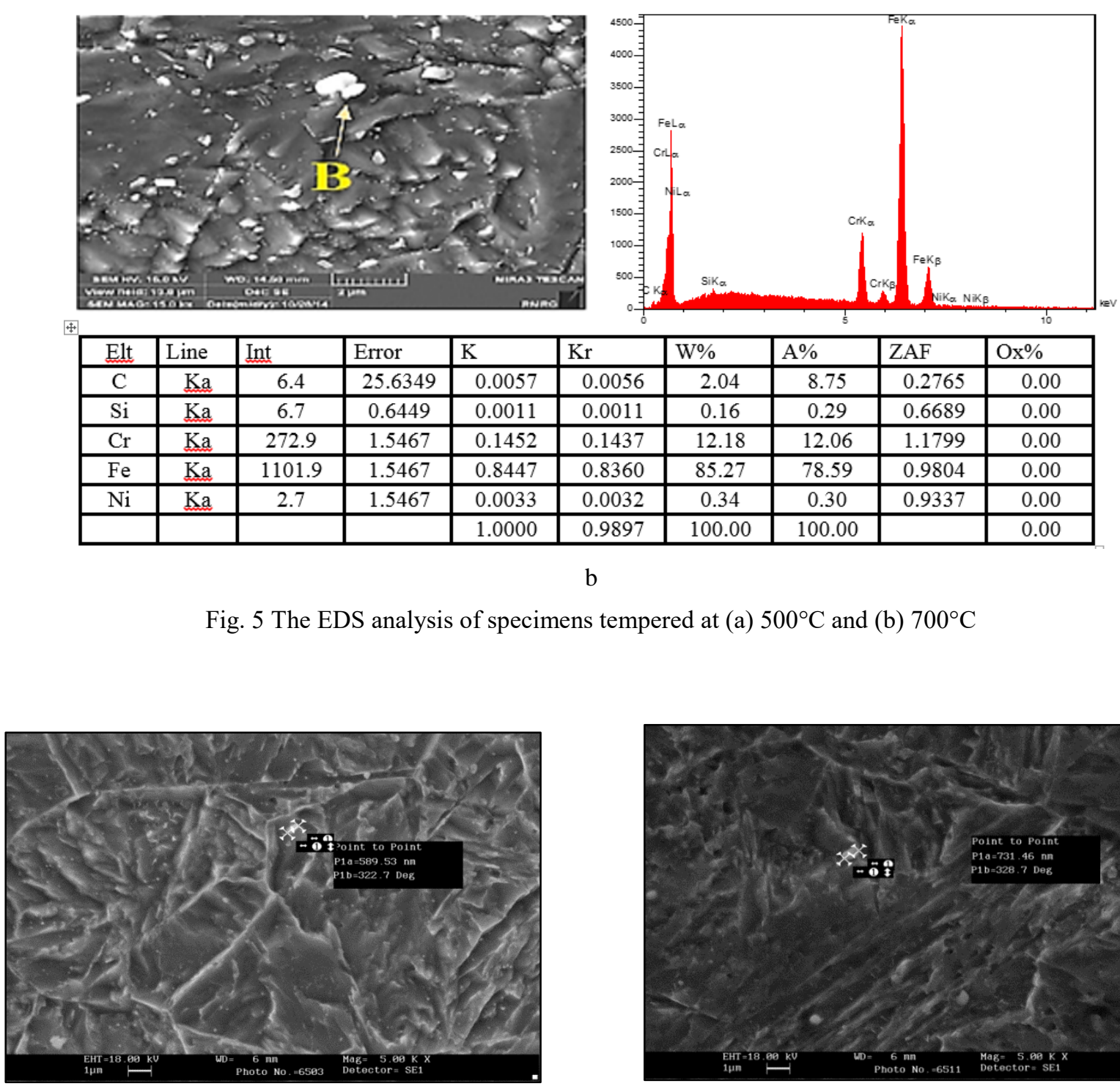

\begin{tabular}{|l|l|l|l|l|}
\hline $\mathrm{Kr}$ & $\mathrm{W} \%$ & $\mathrm{~A} \%$ & $\mathrm{ZAF}$ & $\mathrm{Ox} \%$ \\
\hline 0.0056 & 2.04 & 8.75 & 0.2765 & 0.00 \\
\hline 0.0011 & 0.16 & 0.29 & 0.6689 & 0.00 \\
\hline 0.1437 & 12.18 & 12.06 & 1.1799 & 0.00 \\
\hline 0.8360 & 85.27 & 78.59 & 0.9804 & 0.00 \\
\hline 0.0032 & 0.34 & 0.30 & 0.9337 & 0.00 \\
\hline 0.9897 & 100.00 & 100.00 & & 0.00 \\
\hline
\end{tabular}

b

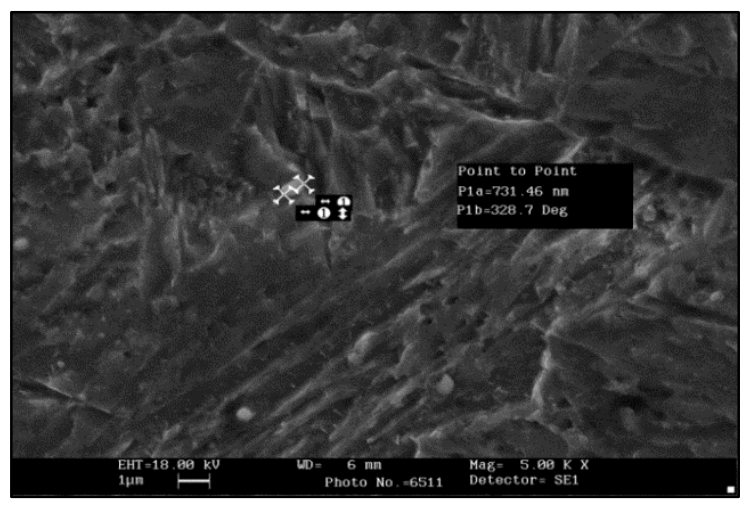

Fig. 6 SEM micrographs: austenitizing at $1040^{\circ} \mathrm{C}$ for $60 \mathrm{~min}$ and tempered at $700^{\circ} \mathrm{C}$ for: $\mathrm{a}-2 \mathrm{~h}$; $\mathrm{b}-5 \mathrm{~h}$

\section{Conclusions}

1. In the range of austenitizing temperature from 1040 to $1070^{\circ} \mathrm{C}$, the austenite grain size increases and the impact energy decreases from 27.7 to $20 \mathrm{~J}$.

2. Secondary hardening took place at the tempering temperature in the range of $400-500^{\circ} \mathrm{C}$ due to the for- 
mation of $\mathrm{M}_{7} \mathrm{C}_{3}$ within the martensite lathes. Softening occurred when the $\mathrm{M}_{7} \mathrm{C}_{3}$ carbides start to coarsen and partially transform to the $\mathrm{M}_{23} \mathrm{C}_{6}$ carbides.

3. A good combination of mechanical properties can be achieved by the austenitizing at $1040^{\circ} \mathrm{C}$ and tempering at $700^{\circ} \mathrm{C}$ for $2 \mathrm{~h}$.

4. With increasing the tempering time from 2 to $5 \mathrm{~h}$, the impact energy increases from 27.7 to $35.1 \mathrm{~J}$, and the cause is understood as the increase of the precipitated carbides size.

\section{References}

1. Garcia de Andres, C.; Alvarez, L.F. 1993. Optimization of properties obtained by quenching martensitic stainless steel X30-40Cr13 and X40-60CrMoV14, Journal of Materials Science 28: 1264-1268. http://dx.doi.org/10.1007/BF01191962.

2. Bhambri, S.K. 1986. Intergranular fracture in $13 \mathrm{wt} \%$ chromium martensitic stainless steel, Journal of Materials Science 21: 1741-1746. http://dx.doi.org/10.1007/BF01114734.

3. Balan, K.P.; Venugopal Reddy, A.; Sarma, D.S. 1999. Effect of single and double austenitization treatments on the microstructure and mechanical properties of $16 \mathrm{Cr}$ 2Ni steel, Journal of Materials Engineering and Performance 8: 385-393. http://dx.doi.org/10.1361/105994999770346963.

4. Porter, D.A 1981. Phase Transformation in Metals and Alloys, Von Nostraned Reinhold.

5. Garcia de Andres, C.; Alvarez, L.F.; Lopez, V. 1998. Effects of carbide-forming elements on the response to thermal treatment of the $\mathrm{X} 45 \mathrm{Cr} 13$ martensitic stainless Steel, Journal of Materials Science 33: 4095-4100. http://dx.doi.org/10.1023/A:1004424329556.

6. Manova, D.; Mandl, S.M. 2005. Wear behavior of martensitic stainless steel after PIII surface treatment, Journal of Surface and Coating Technology 200(1-4): 137-140. http://dx.doi.org/10.1016/j.surfcoat.2005.02.085.

7. NaseryIsfahany, A.; Saghafian, H.; Borhani, Gh. 2011. The effect of heat treatment on mechanical properties and corrosion behavior of AISI420 martensitic stainless steel, Journal of Alloys and Compounds 509: 3931-3936. http://dx.doi.org/10.1016/j.jallcom.2010.12.174.

8. Schafer, L. 1998. Influence of delta ferrite and dendritic carbides on the impact and tensile properties of a martensitic chromium steel, Journal of Nuclear Materials 258-263: 1336-1339. http://dx.doi.org/10.1016/S0022-3115(98)00200-1.

9. Wang, P.; Lu, S.P.; Xiao, N.M.; Li, D.Z.; Li, Y.Y. 2010. Effect of delta ferrite on impact properties of low carbon $13 \mathrm{Cr}-4 \mathrm{Ni}$ martensitic stainless steel, Journal of Materials Science and Engineering: A 527: 3210-3216. http://dx.doi.org/10.1016/j.msea.2010.01.085.

10. Calliari, I.; Zanesco, M.; Dabala, M.; Brunelli, K.; Ramous, E. 2008. Investigation of microstructure and properties of a Ni-Mo martensitic stainless steel, Materials and Design 29: 246-250. http://dx.doi.org/10.1016/j.matdes.2006.11.020.

11. Candelaria, A.F.; Pinedo, C.E. 2003. Influence of the heat treatment on the corrosion resistance of the martensitic stainless steel type AISI 420, Journal of Material
Science Letters 22: 1151-1153.

http://dx.doi.org/10.1023/A:1025179128333.

12. Gonzalez-Rodriguez, J.G.; Bahena-Martinez, G. Salinas-Bravo, V.M. 2000. Effect of heat treatment on the stress corrosion cracking behaviour of 403 stainless steel in $\mathrm{NaCl}$ at $95^{\circ} \mathrm{C}$, Materials Letters 43: 208-214. http://dx.doi.org/10.1016/S0167-577X(99)00261-X.

13. Choi, Y.S.; Kim, J.G.; Park, Y.S.; Park, J.Y. 2007. Austenitizing treatment influence on the electrochemical corrosion behavior of $0.3 \mathrm{C}-14 \mathrm{Cr}-3 \mathrm{Mo}$ martensitic stainless steel, Materials Letters 61: 244-247. http://dx.doi.org/10.1016/j.matlet.2006.04.041.

14. Amini, K.; Hoda, M.R.; Shafyei, A. 2014. Investigation of the effect of heat treatment on the mechanical properties and microstructure of DIN 1.4057 martensitic stainless steel, Journal of Metal Science and Heat Treatment 55: 499-503. http://dx.doi.org/10.1007/s11041-014-9661-9.

15. De-Ning, Z.; Ying, H.; Wei, Zh.; Xu-Dong, F. 2010. Influence of tempering process on mechanical properties of 00Cr13Ni4Mo super martensitic stainless steel, Journal of Iron and Steel Research, International 17(8): 5054.

http://dx.doi.org/10.1016/S1006-706X(10)60128-8.

H. Babaei, K. Amini, A. Shafyei

THE EFFECT OF HEAT TREATMENT ON

MECHANICAL PROPERTIES AND

MICROSTRUCTURE OF THE AISI 422 MARTENSITIC STAINLESS STEEL

S u m m a ry

Martensitic stainless steel has a wide range of applications in steam generators and food industries like mixing blades due to high mechanical and good corrosion resistance. In this research, the effect of austenitizing temperatures $\left(1040^{\circ} \mathrm{C}-1070^{\circ} \mathrm{C}\right)$, tempering temperatures $(300$, $400,500,600$ and $700^{\circ} \mathrm{C}$ ) and also the tempering times of ( 2 and $5 \mathrm{~h}$ ) on microstructure and mechanical properties of martensitic stainless steel X20CrMoWV121(AISI 422) has been investigated. The results of the experiments showed that with increasing the austenitizing temperature from 1040 to $1070^{\circ} \mathrm{C}$ the impact energy is reduced, and the hardness and yield strength are increased. These changes are due to the increase in the austenite grain size. The secondary hardness occurs in the tempering temperature in range of 400$500^{\circ} \mathrm{C}$. The results revealed that after tempering, an increase in hardness and strength and a reduction in toughness occurred in the samples. Also, with increase in the tempering time from 2 to 5 hours at $700^{\circ} \mathrm{C}$, the toughness increased and hardness as well as strength were reduced due to the precipitation of the carbides.

Keywords: Martensitic stainless steel AISI 422, mechanical properties, heat treatment.

Received November 23, 2015 Accepted November 25, 2016 